\title{
Cyanocobalamin and 25-Hydroxy Vitamin D Levels in Gout Patients: An Overlooked Issue
}

\author{
Yunus Emre Yandı1 ${ }^{1}$ Ercan Gencer², Beyza Kılavuz ${ }^{3}$, Ali Erdem Baki ${ }^{4}$, Hatice Şahin³, \\ Muammer Bilici'3 ${ }^{3}$ Metin Işık ${ }^{5}$, Tamer Alışkan' \\ ${ }^{1}$ Division of Biochemistry, Department of Medical Services and Techniques, Health Sciences, Vocational School, \\ Bülent Ecevit University, Zonguldak, Turkey \\ ${ }^{2}$ Department of Physiology, Faculty of Medicine, Bülent Ecevit University, Zonguldak, Turkey \\ ${ }^{3}$ Department of Internal Medicine, Faculty of Medicine, Bülent Ecevit University, Zonguldak, Turkey \\ ${ }^{4}$ Department of Physical Medicine and Rehabilitation, Faculty of Medicine, Bülent Ecevit University, Zonguldak, Turkey \\ ${ }^{5}$ Division of Rheumatology, Department of Internal Medicine, Faculty of Medicine, Bülent Ecevit University, Zonguldak, Turkey \\ ${ }^{6}$ Department of Urology, Faculty of Medicine, Bülent Ecevit University, Zonguldak, Turkey \\ Email: *metin1721978@yahoo.com
}

How to cite this paper: Yand, Y.E., Gencer, E., Kılavuz, B., Baki, A.E., Şahin, H., Bilici, M., Işık, M. and Alışkan, T. (2016) Cyanocobalamin and 25-Hydroxy Vitamin D Levels in Gout Patients: An Overlooked Issue. Open Journal of Rheumatology and Autoimmune Diseases, 6, 96-101.

http://dx.doi.org/10.4236/ojra.2016.64015

Received: April 19, 2016

Accepted: November 1, 2016

Published: November 4, 2016

Copyright $\odot 2016$ by authors and Scientific Research Publishing Inc. This work is licensed under the Creative Commons Attribution International License (CC BY 4.0).

http://creativecommons.org/licenses/by/4.0/ (c) (i) Open Access

\begin{abstract}
Gout is one of the most frequent type of inflammatory arthritis in developed countries. The elevation of serum uric acid levels and the deposition of monosodium urate crystals in joints and/or soft tissues are the mechanisms of pathogenesis. Uric acid is a product of the metabolic cleavage of purine nucleotides and organ meats, beef, pork, and lamb, anchovies, sardines, herring, mackerel, scallops, gravy and beer are known to be very rich in purine. On the other hand, some of these foods are also the main sources of vitamin B12 (cyanocobalamin). As a chronic inflammatory arthritis corticosteroids are frequently prescribed for gout patients, meaning a higher risk for osteoporosis which may be blocked by daily calcium and vitamin D replacement. However, there are no recommendations about screening or replacement of Gout patients for vitamin D and B12. Herein, we evaluated our patients retrospectively to document their vitamin levels and also to find the factors associated with vitamin deficiency. Totally, 90 patients, 71 (79.9\%) male and 19 (20.1\%) female patients with a median diagnostic age of $55(19-80)$ were included. Thirty six (40\%) patients were newly diagnosed (group 1) but $54(60 \%)$ patients had established diseases (group-2) with median disease duration of 36 (11-240) months. Nearly half $(47.2 \%)$ of the patients in group-1 and $37 \%$ of the patients in group- 2 had vitamin B 12 deficiency. Similarly, 38.9\% in each group had vitamin D deficiency and $52.8 \%$ in group-1 and $44.4 \%$ in group-2 had vitamin D insufficiency. In conclusion, we strongly recommend routine screening and replacement of vitamin B12 and D for patients with Gout.
\end{abstract}




\section{Keywords}

Gout, Vitamin B12, Vitamin D

\section{Introduction}

Gout is one of the most frequent rheumatologic diseases in all over the world and in the developed countries gout is the most common type of chronic inflammatory arthritis [1]. Elevation of serum uric acid levels and deposition of monosodium urate crystals in joints and/or soft tissues are the most important facts in the pathogenesis. Uric acid is a product of the metabolic cleavage of purine nucleotides and the normal reference range of plasma uric acid is $3.4-7.2 \mathrm{mg} / \mathrm{dL}(200-430 \mu \mathrm{mol} / \mathrm{L})$ for men, and $2.4-6.1 \mathrm{mg} / \mathrm{dL}$ for women $(140-360 \mu \mathrm{mol} / \mathrm{L})$ [2]. Organ meats, such as liver, kidneys, sweetbreads, brains and meats, including bacon, beef, pork, and lamb, anchovies, sardines, herring, mackerel, and scallops, gravy and beer are known to be very rich in purine and may cause hyperuricemia [3]. On the other hand, some of these foods are also the main sources of vitamin B12 (cyanocobalamin) which is necessary for DNA formation, hematopoiesis and for prevention of neuropathy. Only 75 gr of meat can easily supply the daily vitamin B 12 demand but $1000 \mathrm{ml}$ of milk is necessary for the same purpose [4]. According to novel data nearly $30 \%$ of patients older than 50 years have vitamin B12 deficiency and Health Canada recommend fortified foods for these patients [5]. Interestingly, Gout is more common after fifth decade and diet is an important and routine approach in management of patients with Gout. However, there are no recommendations about screening vitamin B12 levels and replacement therapy [6].

Secondly, Gout is a chronic inflammatory type of arthritis and corticosteroids are frequently prescribed, meaning that these patients are under a higher risk for osteoporosis. Prevention of osteoporosis may be done with daily calcium and vitamin D replacement. Novel data have appointed that vitamin D deficiency is a growing and very important health problem all over the world. Besides heavy diets, prominent weight loss are risk factors for vitamin D deficiency but these approaches are routine for Gout patients meaning that these patients have higher risk for vitamin D deficiency. Similarly, there are no recommendations about screening serum vitamin D levels or replacement therapy [6].

Herein, in this retrospective analysis, we collected the laboratory data of all the Gout patients in our medical database and tried to explore their vitamin B12 and vitamin D status and factors affecting these vitamin levels.

\section{Material and Methods}

All patients, who applied to our outpatient unit between May 2013 and June 2015 with a diagnosis of Gout were included in this retrospectively study. Their gender, age, disease duration, disease activity, serum vitamin B12 and D levels before replacement, presence of uric acid nephropathy and patients with chronic tophaceous Gout were all 
searched and recorded. Uric acid nephropathy was defined as serum creatinine level over $1.4 \mathrm{mg} / \mathrm{dL}$ for men and $1.3 \mathrm{mg} / \mathrm{dL}$ for women. Patients with active arthritis were grouped as active patients and patients without arthritis or elevated $\mathrm{C}$ reactive protein were accepted to be in remission. If the patient was not newly diagnosed as Gout the total follow up durations were also recorded in months. Serum vitamin B12 levels of were classified as deficient $(<200 \mathrm{pg} / \mathrm{ml})$, possible deficient $(200-300 \mathrm{pg} / \mathrm{ml})$ and normal $(>300 \mathrm{pg} / \mathrm{ml})$. Similarly, serum vitamin D level was classified as deficient $(<20$ $\mathrm{ng} / \mathrm{ml})$, insufficient $(20.1-30 \mathrm{ng} / \mathrm{ml})$ and normal (>30 $\mathrm{ng} / \mathrm{ml})$ [7] [8]. For patients with established disease the data about diet compliance was also sought and registered. The study was approved by the local ethics committee.

\section{Statistical Analysis}

Fischer's exact and Chi square test were used for nominal variables, Mann Whitney U test was used for the numeric variables. Repeated-Measure ANOVA tests were used to compare means. All the $\mathrm{p}$ values were 2 -sided and a value less than or equal to 0.05 was considered significant. Statistical Package for Social Sciences version 16.0 (SPSS 16.0) software was used for analysis.

\section{Results}

Totally, there were 90 patients with Gout in our medical database, 71 (79.9\%) male and $19(20.1 \%)$ female patients with a median diagnostic age of $55(19-80)$. The age at diagnosis was not different between female and male patients. Thirty six (40\%) patients were newly diagnosed as Gout (group 1) but 54 (60\%) patients had established diseases (group-2) with median disease duration of $36(11$ - 240) months. Only 9 (25\%) patients in group-1 and 10 (18.5\%) patients group-2 had normal serum vitamin B12 levels. Nearly half (47.2\%) of the patients in group-1 and $37 \%$ of the patients in group-2 had vitamin B 12 deficiency. Similarly, 38.9\% in each group had vitamin D deficiency and $52.8 \%$ in group-1 and $44.4 \%$ in group-2 had vitamin D insufficiency. Disease activity and diet compliance had no effect on vitamin B 12 and D levels. Fifty nine (65.6\%) patients had active disease and 31 (34.4) were in remission. Totally 41 (45.6\%) had nephropathy and 15 (16.7\%) had chronic tophaceous Gout. Patients with nephropathy or tophaceous Gout had similar serum vitamin levels with others. Among patients with established disease 15 (24.2\%) had never been informed about diet and the compliance was poor in $35(56.5 \%)$ patient and the remaining 12 (19.4\%) were fully compliant to the diet (Table 1 and Table 2).

\section{Discussion}

Although diet is an important approach in management of gout patients, screening and replacement of vitamins must not be forgotten.

Andrés M. et al., reviewed 2 randomized controlled trial for vitamin $\mathrm{C}$ and enriched skim milk powder supplement and reported that routine dietary supplementation for Gout patients cannot be recommended because of paucity of high-quality evidence [9]. 
Table 1. Patient characteristics.

\begin{tabular}{|c|c|c|c|}
\hline Parameter & & $\mathrm{N}(90)$ & $\%$ \\
\hline \multirow[t]{2}{*}{ Gender } & Male & 71 & 79.9 \\
\hline & Female & 19 & 20.1 \\
\hline Age at diagnosis (median) & & $55(19-80)$ & \\
\hline Disease duration (median) ${ }^{*}$ & & $36(11-240)$ & \\
\hline \multirow[t]{2}{*}{ Group } & Newly diagnosed & 36 & 40 \\
\hline & Established disease & 54 & 60 \\
\hline \multirow[t]{2}{*}{ Activity } & On acute attack & 59 & 65.6 \\
\hline & In remission & 21 & 34.4 \\
\hline \multirow[t]{3}{*}{ Diet compliance ${ }^{\star *}$} & Poor & 35 & 64.8 \\
\hline & Well & 12 & 22.2 \\
\hline & No diet & 7 & 12.9 \\
\hline \multirow[t]{2}{*}{ Nephropathy ${ }^{* * *}$} & Yes & 41 & 45.6 \\
\hline & No & 49 & 54.4 \\
\hline \multirow[t]{2}{*}{ Chronic tophaceous Gout } & Yes & 15 & 16.7 \\
\hline & No & 75 & 83.3 \\
\hline
\end{tabular}

*established patients, ${ }^{* *}$ totally 54 patients with established disease.

Table 2. Vitamin levels.

\begin{tabular}{cccccc}
\hline Parameter & & Vitamin B 12 & p & Vitamin D & p \\
\hline Disease duration & New patients & 245.4 & 0.657 & 20.8 & 0.523 \\
& Established & 233.9 & & 21.8 & \\
Disease activity & Active & 227.6 & 0.227 & 20.8 & 0.319 \\
& Remission & 259.6 & & 22.4 & \\
Nephropathy & Yes & 224 & & 21.3 & \\
Chronic tophaceous gout & No & 251 & & 21.4 & \\
& Yes & 200 & 0.160 & 20.7 & 0.700 \\
Dietary compliance & No & 246.7 & & 21.5 & \\
& Well & 250 & 0.797 & 20.1 & 0.560 \\
& Poor & 229.8 & & 22 & \\
& Not on a diet & 227.8 & & 23.9 & \\
\hline
\end{tabular}

In 2012, American College of Rheumatology has published a guideline for management of Gout but screening or treatment for vitamin B12 was not discussed [6]. Gout is more frequent among alcoholics and alcohol consumption is a triggering factor for Gout attacks. Furthermore, chronic alcohol consumption is also an important risk factor for vitamin B 12 deficiency, meaning that patients with Gout are under extraincreased risk for vitamin B 12 deficiency [10]. 
On the other hand, Gout patients are under greater risk for osteoporosis because of chronic inflammation and frequent usage of systemic corticosteroids. Furthermore, weight reduction and low purine diet is highly recommended in management of Gout which is risk factor for both vitamin D deficiency and indirectly osteoporosis. That is why we expressly point vitamin D screening and replacement in Gout patients [11].

In our study, $41.1 \%$ and $38.9 \%$ of the study group had vitamin B12 and vitamin D deficiencies, respectively. Compliance to Gout diet was very low, which may explain why the vitamin levels were similar in new and established patients. The educational level of the population increases every day and educated patients are known to be more concerned about their health problems and diet compliance is higher among them. This may, in near future, result with very low vitamin levels causing new complaints and diseases related to these deficiencies. Therefore, placebo controlled trials with larger number of patients and longer follow up periods are necessary to document changes in serum vitamin levels with low purine diet and these trials can provide adequate evidence to recommend routine screening.

\section{Conclusion}

In conclusion, theoretically Gout patients are under extra-increased risk for vitamin $\mathrm{B} 12$ and $\mathrm{D}$ deficiencies and to our data this risk is not only theoretical. To our opinion routine screening and replacement of vitamin B 12 and D is mandatory in Gout.

\section{References}

[1] Kuo, C.F., Grainge, M.J., See, L.C., Yu, K.H., Luo, S.F., Zhang, W. and Doherty, M. (2015) Epidemiology and Management of Gout in Taiwan: A Nationwide Population Study. Arthritis Research \& Therapy, 17, 13.

[2] Karis, E., Crittenden, D.B. and Pillinger, M.H. (2014) Hyperuricemia, Gout, and Related Comorbidities: Cause and Effect on a Two-Way Street. Southern Medical Association, 107, 235-241. http://dx.doi.org/10.1097/SMJ.0000000000000082

[3] Papavasileiou, M.V., Karamanou, A.G., Kalogeropoulos, P., Moustakas, G., Patsianis, S. and Pittaras, A. (2015) Uric Acid Blood Levels and Relationship with the Components of Metabolic Syndrome in Hypertensive Patients. Journal of Human Hypertension, 30, 414-417. http://dx.doi.org/10.1038/jhh.2015.53

[4] Issac, T.G., Soundarya, S., Christopher, R. and Chandra, S.R. (2015) Vitamin B12 Deficiency: An Important Reversible Co-Morbidity in Neuropsychiatric Manifestations. Indian Journal of Psychological Medicine, 37, 26-29.

[5] Ferrand, A., Siu, V.M., Rupar, C.A., Napier, M.P., Al-Dirbashi, O.Y., Chakraborty, P. and Prasad, C. (2015) Biochemical and Hematologic Manifestations of Gastric Intrinsic Factor (GIF) Deficiency: A Treatable Cause of B12 Deficiency in the Old Order Mennonite Population of Southwestern Ontario. JIMD Reports, 18, 69-77. http://dx.doi.org/10.1007/8904_2014_351

[6] Khanna, D., Fitzgerald, J.D., Khanna, P.P., Bae, S., Singh, M.K., Neogi, T., Pillinger, M.H., Merill, J., Lee, S., Prakash, S., Kaldas, M., Gogia, M., Perez - Ruiz, F., Taylor, W., Lioté, F., Choi, H., Singh, J.A., Dalbeth, N., Kaplan, S., Niyyar, V., Jones, D., Yarows, S.A., Roessler, B., Kerr, G., King, C., Levy, G., Furst, D.E., Edwards, N.L., Mandell, B., Schumacher, H.R., Robbins, M., Wenger, N. and Terkeltaub, R. (2012) 2012 American College of Rheumatol- 
ogy Guidelines for Management of Gout. Part 1: Systematic Nonpharmacologic and Pharmacologic Therapeutic Approaches to Hyperuricemia. Arthritis Care \& Research (Hoboken), 64, 1431-1446. http://dx.doi.org/10.1002/acr.21772

[7] Antony, A.C. (2005) Megaloblastic Anemias. In: Hoffman, R., Benz, E.J., Shattil, S.J., et al., Eds., Hematology: Basic Principles and Practice, 4th Edition, Churchill Livingstone, New York, 519.

[8] Carvalho, L.S. and Sposito, A.C. (2015) Vitamin D for the Prevention of Cardiovascular Disease: Are We Ready for That? Atherosclerosis, 241, 729-740.

http://dx.doi.org/10.1016/j.atherosclerosis.2015.06.034

[9] Andrés, M., Sivera, F., Falzon, L., Buchbinder, R. and Carmona, L. (2014) Dietary Supplements for Chronic Gout. Cochrane Database of Systematic Reviews, 10, Article ID: CD010156.

[10] Dalvi, S.R. and Pillinger, M.H. (2013) Saturnine Gout, Redux: A Review. The American Journal of Medicine, 126, 450.e1-450.e8. http://dx.doi.org/10.1016/j.amjmed.2012.09.015

[11] Mody, G.M. and Brooks, P.M. (2012) Improving Musculoskeletal Health: Global Issues. Best Practice \& Research: Clinical Rheumatology, 26, 237-249. http://dx.doi.org/10.1016/j.berh.2012.03.002

Submit or recommend next manuscript to SCIRP and we will provide best service for you:

Accepting pre-submission inquiries through Email, Facebook, LinkedIn, Twitter, etc. A wide selection of journals (inclusive of 9 subjects, more than 200 journals)

Providing 24-hour high-quality service

User-friendly online submission system

Fair and swift peer-review system

Efficient typesetting and proofreading procedure

Display of the result of downloads and visits, as well as the number of cited articles

Maximum dissemination of your research work

Submit your manuscript at: http://papersubmission.scirp.org/

Or contact ojra@scirp.org 